\title{
Current Conditions and Geographical Background Factors of International Marriages: A Case Study of Japan's Tokai Region
}

\author{
NISHIHARA Jun*, ISHIKAWA Yoshitaka**, HIRATSUKA Hitomi*** and \\ KAWASAKI Yukari****
}

\author{
* Faculty of Informatics, Shizuoka University; Hamamatsu 432-8011, Japan. \\ ** Department of Geography, Graduate School of Letters, Kyoto University; Kyoto 606-8501, Japan. \\ *** Seirei Social Welfare Community; Hamamatsu 430-0946, Japan. \\ **** Hitachi Public System Service; Tokyo 136-0075, Japan. \\ E-mail: nishihara@inf.shizuoka.ac.jp*, ishikawa.yoshitaka.4n@kyoto-u.ac.jp**
}

Received September 16, 2011; Accepted September 26, 2012

\begin{abstract}
In this paper, we analyze the current situation of international marriage in the Tokai region, which is one of Japan's most industrialized regions and has a higher rate of international marriage than the national average. We used Vital Statistics of Japan for the region's prefectures (Gifu, Shizuoka, Aichi, and Mie Prefectures) and data from our mailed questionnaire for municipalities to examine the factors of international marriage related to geographical background. These investigations were carried out through correlation and regression analyses at the prefecture, daily-life area, and municipality levels. Consequently, three key findings emerged. First, the Tokai prefectures have different characteristics of spouse nationality in international marriages than those of Japan as a whole. Second, the municipalities with a high international marriage rate are located in underpopulated areas in mountainous and peninsular regions as well as in the highly industrialized areas, especially large cities. Third, the correlation and regression analyses of all 47 prefectures in Japan clarify that the disparities in the sex ratio of unmarried persons, the characteristics of an area's industrialization, and the foreign population are geographical background factors determining the incidence of international marriages. However, as the geographical scale of the analysis became smaller, almost no meaningful geographical background factor could be identified at either the daily-life area or municipal level in the Tokai region.
\end{abstract}

Key words international marriage, sex ratio, geographical background factor, mailed questionnaire, regression analysis

\section{Introduction}

By the late 1980s, the problem of the lack of brides for the male successors of farming households in the peripheral regions of Japan became increasingly serious. In these areas, young men, especially the eldest sons, were expected to assume control of their family farms, get married, and conduct their households based on familyoriented traditions. To address this problem, international marriages with Asian women were strongly promoted in various ways. For instance, a municipal government in Yamagata Prefecture (Figure 1) organized tours for men to visit the Philippines and sponsored arranged-marriage interviews with Filipino women (Sugai 2006). As a result of such activities, international marriages increased in the rural areas of Japan's peripheral regions and drew national attention. This unprecedented type of globalization in Japan's peripheral regions took the nation by surprise.

At the same time, throughout Japan, the rates of both single men and single women skyrocketed in lockstep with the aging phenomenon (Ishikawa 2007a). The unmarried rate ${ }^{1}$ of males aged 30-34 increased from $21.5 \%$ in 1980 to $47.1 \%$ in 2005 , and for females in this age range it rose in the same period from $9.7 \%$ to $32.0 \%$. The reasons included an increase in highly educated young people, more young women in the workforce, and the difficulties faced by women who wanted both children and careers (National Institute of Population and Social Security Research 2007).

As for the educational career and working status of young women, the rate of high-school graduates who entered universities (excluding two-year colleges) increased from $12.3 \%$ in 1980 to $34.5 \%$ in $2003 .^{2}$ The working rate of $25-29$ year-old women also increased from $34.1 \%$ in 1980 to $59.2 \%$ in 2005 , and this rate for the $30-34$ age group rose from $24.9 \%$ to $43.7 \%$ during that period. ${ }^{3}$ As a result, according to the National Institute of Population and Social Security Research (2007), the percentage of 


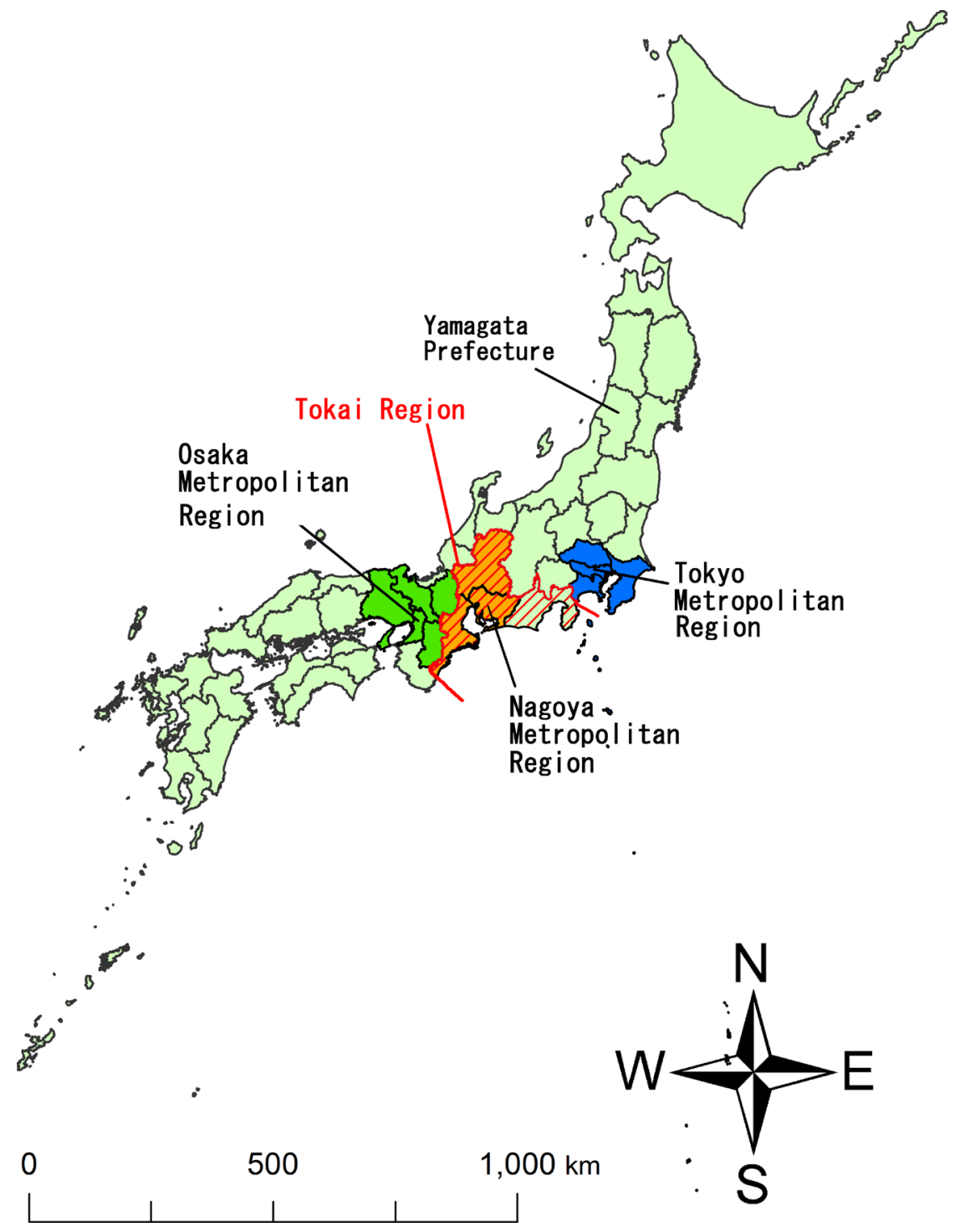

Figure 1. Study area.

single women who wish to get married is $90 \%$, but these women also want economic independence, ${ }^{4}$ forcing them to delay marriage until later in life or perhaps to completely abandon the idea of marriage.

Young men were experiencing nearly the same phenomena. According to the National Institute of Population and Social Security Research (2007), the rate of unmarried men who want to get married is also very high (87.0\%), even though their reasons for remaining single are slightly different, such as economic reasons as well as dating difficulties. Related to the latter reason, the term "herbivorous men" became popular, referring to men who were more interested in hobbies than in relationships with women. Consequently, single men, especially those in their late thirties and forties, have trouble getting married. One solution was international marriage.

Behind these marriage-hindering phenomena lurked what's known as the second demographic transition, which originated in the 1970s in Japan and other industrialized countries. This transition involves population changes that reflect fertility and mortality, specifically the shift from a high-fertility/low-mortality society (resulting from the first demographic transition) to a low-fertility/ low-mortality society. In the latter society, behavioral principles shifted from family-oriented to individualoriented. Examples of such behavioral principles include the rise of unmarried people, one-person households, and highly educated women (Mlädek and Malenchowa 2008).

Due to economic globalization and Japan's economic prosperity from the late 1980s, the foreign population increased in Japan. Furthermore, due to the revisions of the Immigration Control and Refugee Recognition Act in 1990, the number of foreign workers of Japanese ancestry who had settled in such countries as Brazil and Peru in the 1950s and 60s also increased. As a result, both the second demographic transition and economic globaliza- 
Table 1. Trends in international marriages in the four prefectures of the Tokai region

\begin{tabular}{|c|c|c|c|c|c|c|c|c|c|c|c|}
\hline Prefecture & 1997 & 1998 & 1999 & 2000 & 2001 & 2002 & 2003 & 2004 & 2005 & 2006 & 2007 \\
\hline \multirow{2}{*}{$\begin{array}{l}\text { Gifu } \\
\text { Total international marriages } \\
\text { International marriage rate }\end{array}$} & & & & & & & & & & & \\
\hline & 403 & 389 & 348 & 516 & 565 & 527 & 575 & 573 & 738 & 850 & 710 \\
\hline \multirow{3}{*}{$\begin{array}{l}\text { Shizuoka } \\
\text { Total international marriages } \\
\text { International marriage rate }\end{array}$} & & & & & & & & & & & \\
\hline & 810 & 873 & 918 & 998 & 1,044 & 1,063 & 1,116 & 1,324 & 1,471 & 1,659 & 1,288 \\
\hline & $3.6 \%$ & $3.8 \%$ & $4.1 \%$ & $4.2 \%$ & $4.3 \%$ & $4.7 \%$ & $5.1 \%$ & $6.2 \%$ & $7.0 \%$ & $7.7 \%$ & $6.1 \%$ \\
\hline \multirow{3}{*}{$\begin{array}{l}\text { Aichi } \\
\text { Total international marriages } \\
\text { International marriage rate }\end{array}$} & & & & & & & & & & & \\
\hline & 1,888 & 1,837 & 1,841 & 2,318 & 2,490 & 2,384 & 2,434 & 2,652 & 3,220 & 3,901 & 3,682 \\
\hline & $4.0 \%$ & $3.8 \%$ & $4.0 \%$ & $4.8 \%$ & $5.2 \%$ & $5.2 \%$ & $5.4 \%$ & $5.9 \%$ & $7.3 \%$ & $8.4 \%$ & $7.8 \%$ \\
\hline \multicolumn{12}{|l|}{ Mie } \\
\hline Total international marriages & 289 & 349 & 330 & 417 & 468 & 408 & 426 & 427 & 522 & 542 & 536 \\
\hline International marriage rate & $2.7 \%$ & $3.2 \%$ & $3.1 \%$ & $3.7 \%$ & $4.3 \%$ & $3.9 \%$ & $4.2 \%$ & $4.4 \%$ & $5.4 \%$ & $5.5 \%$ & $5.4 \%$ \\
\hline \multicolumn{12}{|l|}{ Japan } \\
\hline Total international marriages & 28,251 & 29,636 & 31,900 & 36,263 & 39,727 & 35,879 & 36,039 & 39,511 & 41,481 & 44,701 & 40,272 \\
\hline International marriage rate & $3.6 \%$ & $3.8 \%$ & $4.2 \%$ & $4.5 \%$ & $5.0 \%$ & $4.7 \%$ & $4.9 \%$ & $5.5 \%$ & $5.8 \%$ & $6.1 \%$ & $5.6 \%$ \\
\hline
\end{tabular}

Data: Vital Statistics of Japan.

tion influenced marriages in Japan. ${ }^{6}$

According to Vital Statistics of Japan prepared by the Ministry of Health, Labor and Welfare, in 1980 there were 774,702 marriages in Japan, 7,261 (0.9\%) of which were international. ${ }^{7}$ Since 1980, the number of international marriages has gradually risen. In 1990 , out of 722,138 marriages, 25,626 (3.5\%) were international, indicating a large increase during the 1980s. Subsequently, international marriages continued to increase in Japan, and both their number and rate reached their highest levels in 2006 (Table 1). ${ }^{8}$ Consequently, international marriages have become a contemporary phenomenon in Japan. They provide one solution for coping with depopulation and the aging society, which severely affect national pensions and health insurance programs (Ishikawa 2007a).

But are international marriages merely a phenomenon in the rural areas of Japan's peripheral regions? The Tokai region, located between Tokyo and Osaka, contains Japan's third-largest metropolitan region, with Nagoya as its central city, and second-largest industrial area with automobile, aerospace, steel, and electronics industries (Figure 1). In this region, the proportion of males is extremely high and the sex ratio is considerably imbalanced, as discussed below. In addition, many foreign workers, notably Japanese-Brazilians and JapanesePeruvians, have settled in this region with their families. As a result, the rate of foreigners in the Tokai region was $1.9 \%$ in 2005 , compared to $1.2 \%$ in the entire country. Furthermore, the Tokai region has many steep mountain ranges, where many municipalities have been designated as Kaso Chiiki (Underpopulated Areas) by the Japanese national government, in addition to highly industrialized areas. The communities in these mountainous districts have experienced substantial depopulation, and thus the men in the local communities also face serious difficulties in getting married.

Because of these conditions in the Tokai region, more international marriages occur there. We would expect these unions to show a variety of patterns, such as Japanese husband and Asian wife, and Japanese spouse and Japanese-Brazilian or Japanese-Peruvian spouse. But how have international marriages actually developed in the Tokai region? What geographical factors lie behind this growth? The rest of this paper will explore these factors and related issues.

\section{Previous Literature and Remaining Issues}

International marriages in Japan have been studied by only a small number of researchers working in a variety of fields, including sociology, cultural anthropology, political science, and home economics. Papers on the underpopulated areas in the peripheral regions of Japan have reported the increase in international marriages and discussed the problems faced by foreign wives (Mitsuoka 1989; Nakazawa 1996; Takeshita 2004; Sugai 2006). However, except for Ishikawa (2007b) and Ochiai et al. (2007), almost no research work has focused on the regional differences in the incident rate of international marriages. These studies on the regional differences in international marriages have focused on the prefectural scale, because the data on international marriages in Vital Statistics of Japan are broken down only at the prefectural level (47 prefectures and 19 national Ordinance-designated Cities). 
Detailed data on the municipal scale are not tabulated in the statistics.

Furthermore, insufficient analysis has been made on the geographical factors behind the development of international marriages. Kojima (1989) pointed out that the imbalanced sex ratio of unmarried young people was a background factor of international marriages. Nakazawa (1996) and Sugai (2006) noted the social background factors for international marriages, such as the marriage squeeze experienced by male successors of farming households who are expected to adhere to familyoriented traditions, young people leaving the local villages, low agricultural income, and three generations living in one household. When discussing the geographical factors underlying the increase in international marriages, however, they presented an indirect and incomplete picture of the overall situation.

Ishikawa (2007b) carried out a regression analysis on all 47 prefectures in 2000, using the international marriage rate as a dependent variable and the sex ratio of unmarried persons of marriageable age as an independent variable. From the obtained regression equation (coefficient of determination $r^{2}=0.394$ ), he found that no causal relationship could be clearly confirmed between the disparity in the sex ratio of unmarried persons and the international marriage rate for the entire nation. Based on the scatter diagram of the international marriage rate and the sex ratio of unmarried persons in the 47 prefectures, however, Ishikawa confirmed causality between these factors in a group of prefectures located in eastern Japan. He concluded that the disparity in the sex ratio of unmarried persons promoted international marriages in that region of Japan.

From the above analysis, we can consider the disparity between the number of unmarried men and women as a major factor in the development of international marriages. As Ishikawa (2007b) indicated, future research must examine regional differences in the incidence rate of international marriages at the municipal level and analyze the relationship between the international marriage rate and the disparity of the sex ratio of unmarried persons on spatial scales lower than the prefecture (e.g., municipal level) by devoting attention to other geographical background factors.

\section{Purpose}

Addressing the tasks described above, our study of the four heavily industrialized prefectures in the Tokai region (Gifu, Shizuoka, Aichi, and Mie Prefectures) has two goals (Figure 2). The first purpose is to examine the situation of international marriages at both the prefectural and municipal levels from the viewpoints of the international marriage rate and the nationalities of foreign spouses.

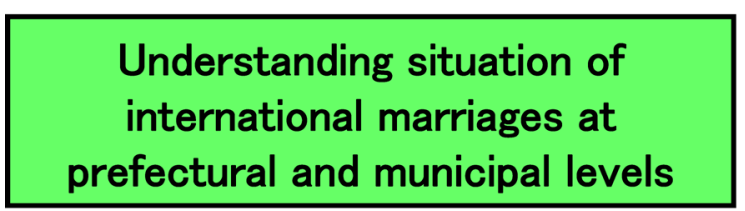

Prefectural level
Vital Statistics of Japan (1997-2007)
Municipal level
Questionnaire survey mailed to municipalities
of Gifu, Shizuoka, Aichi, and Mie Prefectures
(2006)
Data:
- Number of marriages
- Number of international marriages

Study Area: Gifu, Shizuoka, Aichi and Mie Prefectures

\begin{tabular}{|c|c|}
\hline \multicolumn{2}{|c|}{$\begin{array}{c}\text { Analyses of geographical } \\
\text { background factors of international } \\
\text { marriages }\end{array}$} \\
\hline \multicolumn{2}{|c|}{$\begin{array}{l}\text { Correlation coefficient and multiple regression } \\
\text { analyses } \\
\text { D Prefectural level } \\
\text { D Daily-life area level } \\
\text { D Municipal level } \\
\text { Dependent variable: } \\
\quad \text { International marriage rate (2006) } \\
\text { Independent variables: }\end{array}$} \\
\hline $\begin{array}{l}\text { Disparity in sex } \\
\text { ratio of unmarried } \\
\text { persons }\end{array}$ & $\begin{array}{l}\text { - Male/Female sex ratio of unmarried } \\
\text { persons aged } 25-39(2005)\end{array}$ \\
\hline $\begin{array}{c}\text { Area's } \\
\text { industrialization } \\
\text { characteristics }\end{array}$ & $\begin{array}{l}\text { - Rate of primary industry workers (2005) } \\
\text { - Rate of secondary industry workers } \\
\text { (2005) } \\
\text { - Rate of manufacturing sector workers } \\
\text { (2005) } \\
\text { - Rate of production process workers } \\
\text { (2005) }\end{array}$ \\
\hline Foreign population & $\begin{array}{l}\text { - Foreign population rate (2000) } \\
\text { - Increase in rate of foreign population } \\
(2000-05)\end{array}$ \\
\hline
\end{tabular}

Figure 2. Analytical framework. 
The second purpose is to identify geographical factors affecting the development of international marriages at the three spatial scales of prefecture, daily-life area, and municipality. To conduct correlation and regression analyses, we employed the international marriage rate as a dependent variable and, as independent variables, the indices indicating the disparity of the sex ratio of unmarried persons, the area's characteristics of industrialization, and the foreign population.

We chose the Tokai region as the object of our research for the following reasons. First, the development of this region as a manufacturing stronghold has led to a concentration of male workers, and the ratio of unmarried men to unmarried women is unbalanced. According to Japan's Population Census in 2005, the nationwide male/ female sex ratio of unmarried persons aged 25 to 39 was 139.2. In contrast, the ratios in Gifu (146.3), Shizuoka (159.0), Aichi (164.1), and Mie (151.4) Prefectures show a considerably higher male-biased disparity. Furthermore, many Japanese-Brazilians and Japanese-Peruvians are working in Tokai's manufacturing sector. Many daily opportunities to meet Japanese people and get involved with them romantically would also help increase the occurrence of international marriages.

\section{Analytical Framework and Data Used}

\section{Assumed types of international marriage}

According to Vital Statistics of Japan and preliminary interview surveys carried out by the authors, international marriages in the four Tokai prefectures fall into four types:

(1) Japanese males and Asian females: According to Vital Statistics of Japan in 2007, this type comprised $90 \%$ of all international marriages between Japanese men and foreign women in the Tokai region. Some structural factors are believed to explain this pattern. For example, we can assume that the disparity in the sex ratio of unmarried persons is a factor, as demonstrated in Ishikawa (2007b). Because the areas with an imbalance in the sex ratio between unmarried men and women can be divided into rural and industrial districts, this international marriage type can be further divided into two subtypes: (1a) male successors of farming households and Asian females and (1b) blue-collar male workers and Asian females. The evidence for sub-type (1b) will be explored below.

(2) Japanese females and Brazilian/Peruvian males: This reflects the large number of Japanese-Brazil- ians and Japanese-Peruvians living in the Tokai region.

(3) Japanese females and Western males.

(4) Japanese females and Asian males: This includes Korean and Chinese and is the opposite of type (1).

Existing literature has mentioned that international marriage between a Japanese man and a foreign woman, especially type (1), is likely to reflect hypergamy (marrying up) from the foreign woman's side.

\section{Data used and analytical framework}

Our study is composed of two parts corresponding to our goals described above (Figure 2): first, examining the situation of international marriage at prefectural and municipal levels, and second, investigating the geographical background factors of international marriages.

The following data are used in this study. For the prefectural data, the total numbers of marriages and international marriages in the 47 prefectures from 1997 to 2007 are obtained from the Vital Statistics of Japan. Regarding the municipality data, the numbers of marriages and international marriages ${ }^{9}$ and spouse nationalities of international marriages as of 2006 are collected from our questionnaires that we mailed to all of the municipalities in the Tokai region in 2007 and 2008. Although we obtained data on the numbers of all marriages and the international marriages of 146 municipalities $^{10}$ in 2006, we could only obtain data on the nationalities of the spouses from 104 of them. The following are the response rates of our survey: 35 valid responses out of 42 municipalities ( $83 \%$ response rate) for Gifu, 34 responses of 44 municipalities (77\%) for Shizuoka, 55 responses of 78 municipalities (71\%) for Aichi, and 22 responses of 29 municipalities (75\%) for Mie.

For the correlation and regression analyses conducted to examine the geographical background factors behind the development of international marriages, we used the three groups of independent variables based on the assumed typical international marriage types described above (Figure 2).

We postulate that the disparity in the sex ratio of unmarried persons is the most basic geographical background factor for international marriage sub-types (1a) and (1b). It is also postulated that the actual difference in the rate of international marriages reflects the characteristics of the basic industries in rural (sub-type (1a)) and industrial areas (sub-type (1b)). In other words, the area's industrialization characteristics, as the second factor group, appear to affect the increase in international marriages as a condition underlying the disparity in the 
sex ratio of unmarried persons. Furthermore, since many international marriages are found in regions with large foreign populations, the foreign population indices are applied as the third factor group, corresponding to types (2), (3), and (4). Here, the rate of international marriages in these patterns has been increasing due to the additional opportunities for Japanese people and foreigners to meet and get to know each other.

Next, for the three independent variable groups (Figure 2 ), we selected as specific indicators 1) sex ratio of unmarried persons aged $25-39,{ }^{11}$ 2) the rates of primary industry workers, secondary industry workers, manufacturing sector workers, and production process workers, and 3) the foreign population rate and the rate of increase in the foreign population. For the group of the area's industrialization characteristics, the rate of the primary industrial workers was chosen as an indicator of rurality, and the other variables were selected as indicators of a regional economy led by manufacturing and blue-collar workers.

We investigate the year 2006 in the correlation and regression analyses, when the number and rate of international marriages peaked in both Japan and the Tokai region. For the data of the variables other than the foreign population rate, we used the Population Census in 2005. Because the foreign population rate is also influenced by the results of international marriages, we used data from 2000 for the foreign population rate and data from 2000-2005 for the rate of increase in the foreign population.

The daily-life areas (nichijo seikatsu ken) were also analyzed as an additional spatial scale at an intermediate level between prefectures and municipalities. This spatial level represents the commuting areas of central cities, since the extent of daily mobility by inhabitants are not restricted within municipal boundaries. Actually, as daily-life areas, we used the administrative regions for higher-level public services organized by the Gifu, Shizuoka, Aichi, and Mie prefectural governments. Such regions are delineated by all of the prefectural governments in Japan, based on the service or commuting areas of the central cities and the administrative territories of the branch offices of the prefectural governments. Therefore, our correlation and regression analyses were conducted at the three spatial scales of prefecture, daily-life area and municipality, i.e., from wider to narrower spatial units.

\section{Actual Conditions of International Marriages in the Tokai Region}

\section{Characteristics of international marriages in prefectures}

First, we compare the situation in the four Tokai prefectures with all of Japan in 2006 using the data of Vital Statistics of Japan (Figure 3). As mentioned above, the number $(44,701)$ and rate $(6.1 \%)$ of international marriages in Japan reached their zenith in 2006. The prefectures where the percentages of international marriages exceeded $7.5 \%$ are located in central Japan and are classified into three groups. The territory of the first group (Tokyo, Chiba, Gunma, Saitama, and Kanagawa) is nearly equivalent to the entire Tokyo metropolitan region. The second group (Aichi, Gifu and Shizuoka) is comprised of the prefectures of the Tokai region, excluding Mie Prefecture. The prefectures of the third group (Yamanashi and Nagano) are in the mountainous region between the Tokyo metropolitan region and the Tokai region. From the viewpoint of the national rate (6.1\%), the prefectures with international marriage rates over $6 \%$ are confined to the slightly expanded central part of Japan including Osaka, which is a central area of the second-largest metropolitan region. Conversely, the international marriage

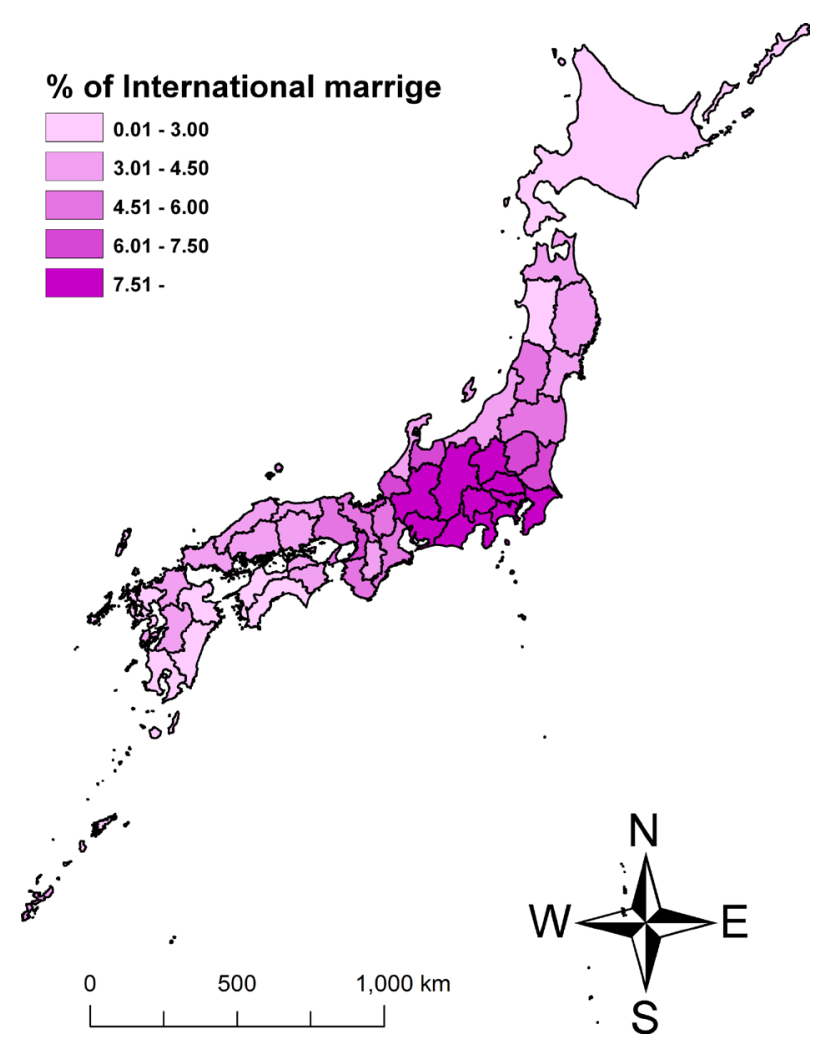

Figure 3. International marriage rate by prefecture (2006).

Data: Vital Statistics of Japan in 2006. 
rates of the prefectures in the peripheral regions are relatively low, which seems counterintuitive because many new foreign brides came to the rural areas of these regions. In fact, in terms of volume, the number of international marriages of type (1) (Japanese husband and Asian wife) is not so large among all marriages there, including non-international marriages. However, new brides from Asian countries still account for a large share of the new arrivals of foreigners. ${ }^{12}$

Second, we report on the international marriage characteristics at the prefectural level from 1997 to 2007 in the four Tokai prefectures using Vital Statistics of Japan (Table 1). During the study period, the number of international marriages and the international marriage rate significantly increased in the Tokai region. Table 1 shows the changes in the figures from 1997 to 2007: 403 international marriages and $3.4 \%$ to 710 international marriages and $6.6 \%$ in Gifu; 810 marriages and $3.6 \%$ to 1,288 marriages and $6.1 \%$ in Shizuoka; 1,888 marriages and $4.0 \%$ to 3,682 marriages and $7.8 \%$ in Aichi; 289 marriages and $2.7 \%$ to
536 marriages and $5.4 \%$ in Mie. On the other hand, the corresponding number and rate during the same period for Japan as a whole was 28,251 marriages and 3.6\% to 40,272 marriages and 5.6\%. The increase in the Tokai region obviously exceeded the nationwide growth. Interestingly, international marriages were especially numerous in Gifu, Shizuoka, and Aichi.

Next, the compositions of Japanese husbands and foreign wives and Japanese wives and foreign husbands among international marriages are discussed (Table 2). Overall for international marriages, the proportion of couples composed of Japanese husbands and foreign wives was high in all four prefectures: $88.9 \%$ in Gifu, $86.0 \%$ in Shizuoka, $82.5 \%$ in Aichi, and $81.7 \%$ in Mie. These levels exceeded the nationwide rate $(79.0 \%)$ and seem to reflect the high sex ratio of unmarried males to unmarried females.

Furthermore, based on Vital Statistics of Japan in 2007, we examined the proportion of the nationalities for each sex of foreign spouses in 2007 (Table 2). For the nation-

Table 2. Nationality of foreign spouses in the four prefectures of the Tokai region (2007)

\begin{tabular}{|c|c|c|c|c|c|c|c|c|c|c|}
\hline $\begin{array}{c}\text { Japanese } \\
\text { husband } \\
\text { and foreign } \\
\text { wife }\end{array}$ & Total & Korea & China & Philippines & Thailand & U.S.A. & U.K. & Brazil & Peru & Others \\
\hline $\begin{array}{c}\text { Gifu } \\
(88.9 \%)\end{array}$ & $\begin{array}{r}631 \\
100.0 \%\end{array}$ & $\begin{array}{r}41 \\
6.5 \%\end{array}$ & $\begin{array}{r}189 \\
30.0 \%\end{array}$ & $\begin{array}{r}326 \\
51.7 \%\end{array}$ & $\begin{array}{r}11 \\
1.7 \%\end{array}$ & $\begin{array}{r}2 \\
0.3 \%\end{array}$ & $\begin{array}{r}0 \\
0.0 \%\end{array}$ & $\begin{array}{r}9 \\
1.4 \%\end{array}$ & $\begin{array}{r}4 \\
0.6 \%\end{array}$ & $\begin{array}{r}49 \\
7.8 \%\end{array}$ \\
\hline $\begin{array}{c}\text { Shizuoka } \\
(86.0 \%)\end{array}$ & $\begin{array}{r}1107 \\
100.0 \%\end{array}$ & $\begin{array}{r}108 \\
9.8 \%\end{array}$ & $\begin{array}{r}290 \\
26.2 \%\end{array}$ & $\begin{array}{r}510 \\
46.1 \%\end{array}$ & $\begin{array}{r}45 \\
4.1 \%\end{array}$ & $\begin{array}{r}2 \\
0.2 \%\end{array}$ & $\begin{array}{r}2 \\
0.2 \%\end{array}$ & $\begin{array}{r}39 \\
3.5 \%\end{array}$ & $\begin{array}{r}12 \\
1.1 \%\end{array}$ & $\begin{array}{r}99 \\
8.9 \%\end{array}$ \\
\hline $\begin{array}{c}\text { Aichi } \\
(82.5 \%)\end{array}$ & $\begin{array}{r}3,039 \\
100.0 \%\end{array}$ & $\begin{array}{r}359 \\
11.8 \%\end{array}$ & $\begin{array}{r}732 \\
24.1 \%\end{array}$ & $\begin{array}{r}1,550 \\
51.0 \%\end{array}$ & $\begin{array}{r}47 \\
1.5 \%\end{array}$ & $\begin{array}{r}11 \\
0.4 \%\end{array}$ & $\begin{array}{r}5 \\
0.2 \%\end{array}$ & $\begin{array}{r}42 \\
1.4 \%\end{array}$ & $\begin{array}{r}11 \\
0.4 \%\end{array}$ & $\begin{array}{r}282 \\
9.3 \%\end{array}$ \\
\hline $\begin{array}{c}\text { Mie } \\
(81.7 \%)\end{array}$ & $\begin{array}{r}438 \\
100.0 \%\end{array}$ & $\begin{array}{r}31 \\
7.1 \%\end{array}$ & $\begin{array}{r}159 \\
36.3 \%\end{array}$ & $\begin{array}{r}137 \\
31.3 \%\end{array}$ & $\begin{array}{r}42 \\
9.6 \%\end{array}$ & $\begin{array}{r}0 \\
0.0 \%\end{array}$ & $\begin{array}{r}1 \\
0.2 \%\end{array}$ & $\begin{array}{r}10 \\
2.3 \%\end{array}$ & $\begin{array}{r}6 \\
1.4 \%\end{array}$ & $\begin{array}{r}52 \\
11.9 \%\end{array}$ \\
\hline $\begin{array}{l}\text { JAPAN } \\
(79.0 \%)\end{array}$ & $\begin{array}{r}31,807 \\
100.0 \%\end{array}$ & $\begin{array}{r}5,606 \\
17.6 \% \\
\end{array}$ & $\begin{array}{r}11,926 \\
37.5 \% \\
\end{array}$ & $\begin{array}{r}9,217 \\
29.0 \% \\
\end{array}$ & $\begin{array}{l}1,475 \\
4.6 \% \\
\end{array}$ & $\begin{array}{r}193 \\
0.6 \% \\
\end{array}$ & $\begin{array}{r}67 \\
0.2 \% \\
\end{array}$ & $\begin{array}{r}288 \\
0.9 \% \\
\end{array}$ & $\begin{array}{r}138 \\
0.4 \% \\
\end{array}$ & $\begin{array}{r}2,897 \\
9.1 \%\end{array}$ \\
\hline $\begin{array}{l}\text { Japanese } \\
\text { wife and } \\
\text { foreign } \\
\text { husband }\end{array}$ & Total & Korea & China & Philippines & Thailand & U.S.A. & U.K. & Brazil & Peru & Others \\
\hline $\begin{array}{c}\text { Gifu } \\
(11.1 \%)\end{array}$ & $\begin{array}{r}79 \\
100.0 \%\end{array}$ & $\begin{array}{r}10 \\
12.7 \%\end{array}$ & $\begin{array}{r}5 \\
6.3 \%\end{array}$ & $\begin{array}{r}2 \\
2.5 \%\end{array}$ & $\begin{array}{r}0 \\
0.0 \%\end{array}$ & $\begin{array}{r}7 \\
8.9 \%\end{array}$ & $\begin{array}{r}6 \\
7.6 \%\end{array}$ & $\begin{array}{r}17 \\
21.5 \%\end{array}$ & $\begin{array}{r}3 \\
3.8 \%\end{array}$ & $\begin{array}{r}29 \\
36.7 \%\end{array}$ \\
\hline $\begin{array}{c}\text { Shizuoka } \\
(14.0 \%)\end{array}$ & $\begin{array}{r}181 \\
100.0 \%\end{array}$ & $\begin{array}{r}22 \\
12.2 \%\end{array}$ & $\begin{array}{r}14 \\
7.7 \%\end{array}$ & $\begin{array}{r}6 \\
3.3 \%\end{array}$ & $\begin{array}{r}1 \\
0.6 \%\end{array}$ & $\begin{array}{r}12 \\
6.6 \%\end{array}$ & $\begin{array}{r}6 \\
3.3 \%\end{array}$ & $\begin{array}{r}44 \\
24.3 \%\end{array}$ & $\begin{array}{r}12 \\
6.6 \%\end{array}$ & $\begin{array}{r}64 \\
35.4 \%\end{array}$ \\
\hline $\begin{array}{c}\text { Aichi } \\
(17.5 \%)\end{array}$ & $\begin{array}{r}643 \\
100.0 \%\end{array}$ & $\begin{array}{r}186 \\
28.9 \%\end{array}$ & $\begin{array}{r}46 \\
7.2 \%\end{array}$ & $\begin{array}{r}18 \\
2.8 \%\end{array}$ & $\begin{array}{r}2 \\
0.3 \%\end{array}$ & $\begin{array}{r}40 \\
6.2 \%\end{array}$ & $\begin{array}{r}19 \\
3.0 \%\end{array}$ & $\begin{array}{r}80 \\
12.4 \%\end{array}$ & $\begin{array}{r}15 \\
2.3 \%\end{array}$ & $\begin{array}{r}237 \\
36.9 \%\end{array}$ \\
\hline $\begin{array}{c}\text { Mie } \\
(18.3 \%)\end{array}$ & $\begin{array}{r}98 \\
100.0 \%\end{array}$ & $\begin{array}{r}27 \\
27.6 \%\end{array}$ & $\begin{array}{r}3 \\
3.1 \%\end{array}$ & $\begin{array}{r}1 \\
1.0 \%\end{array}$ & $\begin{array}{r}0 \\
0.0 \%\end{array}$ & $\begin{array}{r}7 \\
7.1 \%\end{array}$ & $\begin{array}{r}1 \\
1.0 \%\end{array}$ & $\begin{array}{r}20 \\
20.4 \%\end{array}$ & $\begin{array}{r}4 \\
4.1 \%\end{array}$ & $\begin{array}{r}35 \\
35.7 \%\end{array}$ \\
\hline $\begin{array}{c}\text { JAPAN } \\
(21.0 \%)\end{array}$ & $\begin{array}{r}8,465 \\
100.0 \%\end{array}$ & $\begin{array}{r}2,209 \\
26.1 \%\end{array}$ & $\begin{array}{r}1,016 \\
12.0 \%\end{array}$ & $\begin{array}{r}162 \\
1.9 \%\end{array}$ & $\begin{array}{r}68 \\
0.8 \%\end{array}$ & $\begin{array}{r}1,485 \\
17.5 \%\end{array}$ & $\begin{array}{r}372 \\
4.4 \%\end{array}$ & $\begin{array}{r}341 \\
4.0 \%\end{array}$ & $\begin{array}{r}127 \\
1.5 \%\end{array}$ & $\begin{array}{r}2,685 \\
31.7 \%\end{array}$ \\
\hline
\end{tabular}

Data: Vital Statistics of Japan.

Note: \% in parentheses in far left column under prefecture name is ratio of couples of Japanese husbands/wives to the total number of international marriage couples. 
alities of foreign wives in Gifu and Shizuoka Prefectures in 2007, the highest proportion was Filipino, followed by Chinese and Korean. In Gifu, the proportion of Filipinos (51.7\%) was particularly high, as it was to a lesser extent in Shizuoka (46.1\%). In Aichi in 1999, the ranking of nationalities was Filipino, Korean, and Chinese. However, the order of second and third places changed from 2007, when the ranking was 51.0\% for Filipino, 24.1\% for Chinese, and $11.8 \%$ for Korean. In Mie, while Filipino and Chinese have both been represented by large proportions since 2000, Chinese accounted for the largest proportion in 2007.

In terms of foreign wives' nationality in Japan as of 2007, first-place Chinese (37.5\%) and second-place Filipino (29.0\%) each roughly comprised one-third of all nationalities, while Korean made up only $17.6 \%$. In the Tokai region, the proportion of Filipino wives surpassed the national proportion probably because many Filipinos gathered in cities of the Tokai region. According to Statistics on Foreigners Registered in Japan in 2006, Nagoya City (3rd), Hamamatsu City (5th), and five other cities in the Tokai region ranked among the top twenty cities in Japan for the number of Filipinos. According to Chiba (2012), since the second half of the 1990s, Filipinos were highly concentrated in the Tokai region, and about $80 \%$ of them were females. Takahata (2011) pointed out that from the late 1980 s to $2005,{ }^{13}$ many Filipino females came to Japan, especially to the Tokai region, as dancers and singers. "Philippine pubs" employing Filipino women were established in numerous cities of the Tokai region as well as all over Japan (Abe 2003). As a result, since the 1990s, many of those Filipino women married Japanese men in this region. After their marriages, the Filipino wives often introduced their sisters and relatives still in the Philippines to Japanese males for international marriages.

As for the nationalities of foreign husbands, no nationality accounted for more than one-third. In the Tokai region in 1997, Korean had the largest share, but the proportion of Brazilian and Peruvian has grown since then. In all four Tokai prefectures, the rates of the couples of Brazilian husband/Japanese wife and Peruvian husband/ Japanese wife (international marriage type (2)) greatly exceeded the nationwide figures; in the three prefectures excluding Aichi, this type accounted for a quarter of the region's international marriages between foreign husbands and Japanese wives in 2007 (Table 2). The high number of Japanese-Brazilian and Japanese-Peruvian workers who settled in this region certainly explains this phenomenon. In this way, we identified the existence of international marriage type (2) in the region.

\section{Characteristics of international marriage rates in municipalities}

The results of our questionnaire mailed to the municipalities in the Tokai region on international marriage rates (2006) are shown in Table 3 and Figure 4. We obtained data from 148 municipalities. ${ }^{14}$ First, the spatial variation of the international marriage rate is greater among municipalities within a particular prefecture than among the prefectures themselves for all four prefectures. Second, the municipalities with higher rates do not necessarily correspond to smaller municipalities.

A quick look at the municipalities with higher rates reveals six over $15 \%$ and six from $12 \%$ to $15 \%$. These 12 municipalities are Hichiso (15.4\%), Tomika (15.0\%), and Shirakawa Towns (13.6\%) in Gifu, Nishiizu Town (17.2\%), Atami City (16.1\%), Omaezaki City (14.6\%), Arai Town (12.3\%), and Numazu City (12.1\%) in Shizuoka, Shitara (27.3\%), Kasuga (23.7\%), Hazu (19.1\%), and Kozakai Towns (12.5) in Aichi, and none in Mie (Figure 4). With the exception of Numazu and Atami Cities, the populations of these municipalities are relatively small. The international marriage rates in these ten municipalities were high because, since the total number of marriages in these municipalities was small, a single and sporadic international marriage carried heavier weight than in other municipalities with large populations. However, when we discuss municipalities with rates from $9 \%$ to $12 \%$, there are many cities with large populations in such industrial municipalities as Mino (11.0\%), Gifu (10.7\%), Kagamigahara (9.5\%), and Tajimi Cities (9.1\%) in Gifu Prefecture, and Iwakura (10.3\%), Nagoya (9.9\%), Tokoname (9.9\%), Toyohashi (9.8\%), Kasugai (9.4\%), and Tahara Cities (9.3\%) in Aichi.

The locations of municipalities whose international marriage rates exceeded 9\%, shown in Figure 4, lead us to identify two kinds of municipality groups: those with small populations in the mountainous areas and those of large cities with a strong manufacturing sector. Roughly speaking, in Gifu Prefecture, those small municipalities are located in the upstream areas of the Hida and Nagara Rivers. ${ }^{15}$ The large cities with high international marriage rates, such as Gifu, Tajimi, and Kagamigahara, are located in the manufacturing area. The municipalities with rates over 9\% in Shizuoka correspond to the underpopulated area of the Izu Peninsula or the manufacturing area in the western part of the prefecture. Many Brazilians and Peruvians live in such industrial regions. In Aichi Prefecture, municipalities with rates over $9 \%$ are located in the upstream region of the Toyo River, an underpopulated area, as represented by Shitara Town. Another group of 


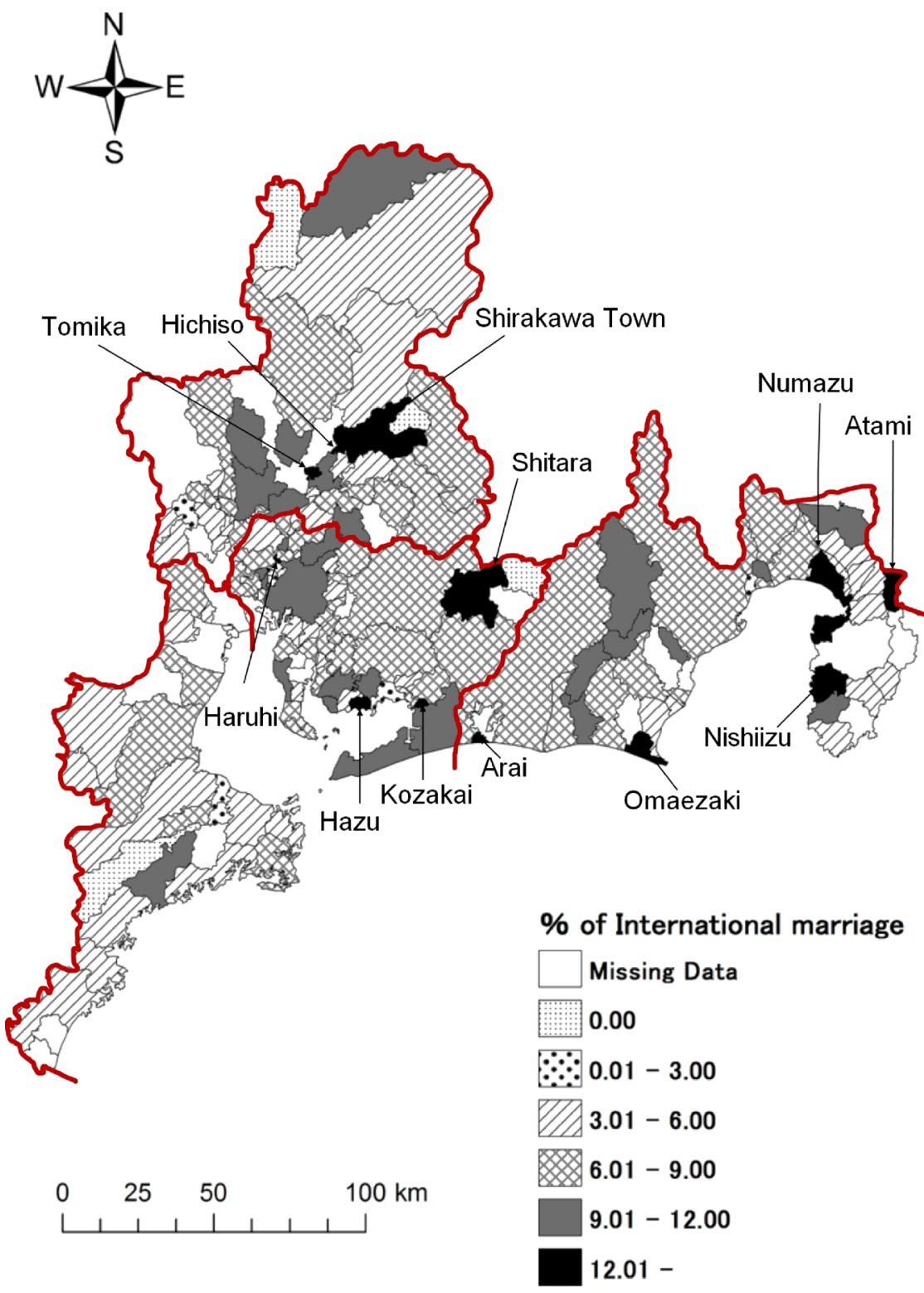

Figure 4. International marriage rate by municipality (2006).

Data: Authors' mailed questionnaire survey.

Table 3. Number of municipalities by level of international marriage rate (2006) and status of "Underpopulated" or "Nonunderpopulated" area

\begin{tabular}{|c|c|c|c|c|c|c|}
\hline \multirow{3}{*}{$\begin{array}{l}\text { International } \\
\text { marriage rate }\end{array}$} & \multicolumn{2}{|c|}{ Total } & \multicolumn{2}{|c|}{ Underpopulated Area } & \multicolumn{2}{|c|}{ Non-underpopulated Area } \\
\hline & \multicolumn{2}{|c|}{ Municipalities } & \multicolumn{2}{|c|}{ Municipalities } & \multicolumn{2}{|c|}{ Municipalities } \\
\hline & No. & $\%$ & No. & $\%$ & No. & $\%$ \\
\hline $\begin{array}{l}\text { No international } \\
\text { marriage }\end{array}$ & 6 & 4.1 & 4 & 12.9 & 2 & 1.7 \\
\hline $0.01 \%-3.00 \%$ & 7 & 4.7 & 0 & 0.0 & 7 & 6.0 \\
\hline $3.01 \%-6.00 \%$ & 44 & 28.4 & 9 & 29.0 & 35 & 29.9 \\
\hline $6.01 \%-9.00 \%$ & 52 & 36.5 & 7 & 22.6 & 45 & 38.5 \\
\hline $9.01 \%-12.00 \%$ & 27 & 18.2 & 6 & 19.4 & 21 & 17.9 \\
\hline $12.01 \%-15.00 \%$ & 6 & 3.4 & 2 & 6.5 & 4 & 3.4 \\
\hline $15.01 \%$ and over & 6 & 4.7 & 3 & 9.7 & 3 & 2.6 \\
\hline Total & 148 & 100.0 & 31 & 100.0 & 117 & 100.0 \\
\hline
\end{tabular}

Data: Authors' mailed questionnaire survey. Note: Underpopulated Areas were designated by the Japanese national government. 
municipalities are in the industrial region, as represented by Nagoya, Toyohashi, and Kasugai Cities.

To further discuss the regional characteristics of the international marriage rate, we referenced ranges of this rate against the number of municipalities in underpopulated and in non-underpopulated areas, based on the designations established by the Japanese national government (Table 3). ${ }^{16}$ Consequently, the municipalities located in the underpopulated areas have a frequency distribution slightly biased toward either a higher or a lower international marriage rate than those in the nonunderpopulated areas.

As a result of examining the magnitude of the international marriage rate in terms of the municipal scale, it might be reasonable to assume that sub-type (1a) is applicable to the underpopulated municipalities in the mountainous and peninsular areas, while sub-type (1b) and type (2) apply to industrial areas where many Japanese blue-collar workers and many Japanese-Brazilians and Japanese-Peruvians live. However, this tentative conclusion should be treated with caution. Interesting exceptions are Atami City in Shizuoka and Shima City in Mie, which, as important tourism destinations, also exhibit a higher international marriage rate but require a different explanation.

\section{Characteristics of spouse nationalities in municipalities}

The top two nationalities of foreign spouses in the municipalities of the four Tokai prefectures are listed in Table 4. As discussed above, even though we mailed questionnaires to all 193 municipalities and received data on the number of international marriages from 146 municipalities, we were only able to gather information on the nationality of spouses from 104 municipalities: 26 in Gifu, 19 in Shizuoka, 41 in Aichi, and 18 in Mie. Although the nationality data of spouses cannot be disaggregated by sex, it is likely that the nationalities of foreign wives, who made up a considerably high percentage of international marriages, heavily affected the weight of the results of our analysis on the nationality of spouses.

The ranking of the nationalities of foreign spouses in the municipalities in Gifu Prefecture closely resembled the prefecture-wide feature (first Filipino, second Chinese and third Korean) noted in the Vital Statistics of Japan in 2006. Of the 26 municipalities from which data were obtained, Filipinos ranked first in 20 of them. In the ten municipalities, the order was Filipinos first and Chinese second, including some ties. In contrast, there were only four municipalities in which Chinese occupied first place alone. In one municipality, Brazilian was second.

In Shizuoka Prefecture, where the overall ranking is Filipino first, Chinese second and Korean third, in 12 municipalities, Filipinos occupied the top position, and in five they were tied for first. Although many Brazilians and Peruvians have settled in this prefecture, there were no municipalities in which Brazilian or Peruvian nationality placed higher than third.

Next we consider the nationality rankings of the foreign spouses in 41 municipalities in Aichi, where the prefecture-wide ranking by Vital Statistics of Japan showed Filipinos as first followed by Chinese and Koreans. Filipinos ranked first alone in 31 municipalities, and in three municipalities they shared the top ranking with Chinese, based on our questionnaire data. In short, Filipinos overwhelmingly held the top position in this prefecture. In contrast, Chinese ranked first in ten municipalities, sharing the top ranking with Filipinos in three of those ten municipalities. The second-place nationalities shown as "others" in Table 4 included American, Ukrainian, Nigerian, Vietnamese, Turkish, Romanian, Thai, and Pakistani, showing the widely internationalized or globalized character of Aichi Prefecture.

Of the 18 municipalities in Mie, Filipinos occupied first place in only four and shared it in five municipalities with Chinese or other nationalities. Chinese occupied first place in five municipalities (including ties), indicating the relatively large proportion of Chinese spouses in this prefecture. Furthermore, partly because the number of international marriages was low, the nationalities of the spouses were somewhat scattered.

Except for Mie Prefecture, the Tokai municipalities frequently had a ranking of Filipinos in first place and Chinese in second place, which differed from Japan as a whole. However, in a great majority of the municipalities studied in the Tokai region, including those of the underpopulated areas, the Chinese nationality occupied first or second place in Table 4. According to Ishikawa (2010), at least one third of all international marriages in Japan in 2006 were considered to be arranged by matchmaking agencies, and $70 \%$ of those agency-brokered foreign brides in registered international marriages were Chinese. This seems to suggest the importance of such agencies even in this region.

Since many Japanese-Brazilians and JapanesePeruvians are living in the Tokai region, we also expected an increase in the international marriages between them and Japanese nationals (international marriage type (2)). However, we found very few municipalities in which Brazilian or Peruvian occupied the top spot of spouse na- 
Table 4. Ranking of nationalities of foreign spouses in the municipalities of the Tokai region

\begin{tabular}{|c|c|c|}
\hline \multicolumn{3}{|l|}{ Gifu Prefecture $=26$} \\
\hline First place & Second place & Municipalities (number of total international marriages in 2006) \\
\hline \multirow{5}{*}{ Philippines $=16$} & China & $\begin{array}{l}\text { Gifu(267), Tajimi(47), Kani(45), Hashima(32), Mizuho(25), Gujo(13), Ono(6), } \\
\text { Mitake(5), Tomika(3) }\end{array}$ \\
\hline & China \& U.K. & Gero(9) \\
\hline & Korea & Yamagata(14), Yaotsu(3) \\
\hline & Korea \& Others & Mino(11) \\
\hline & Others & Ginan(15), Sakahogi(2), Kawabe(2) \\
\hline Philippines \& Other $=4$ & & Motosu(11), Godo(7), Tarui(2), Hichiso(2) \\
\hline \multirow{3}{*}{ China $=4$} & Philippines & Ikeda(8), Shirakawa Town(3) \\
\hline & Philippines \& Others & Hida(10) \\
\hline & & Sekigahara(1) \\
\hline China \& Brazil = 1 & & Wanouchi(2) \\
\hline Korea $=1$ & Philippines \& China & Anpachi(4) \\
\hline \multicolumn{3}{|l|}{ Shizuoka Prefecture $=19$} \\
\hline \multirow{5}{*}{ Philippines $=12$} & China & Fujinomiya(51), Susono(18), Oigawa*(8), Higashiizu(3) \\
\hline & China \& Korea & Nagaizumi(13) \\
\hline & China \& Others & Omaezaki(30), Nishiizu(5), Okabe*(4) \\
\hline & Korea & Fuji(121), Gotenba(57) \\
\hline & & Shibakawa*(3), Kawane*(2) \\
\hline Philippines \& China =3 & & Mishima(30), Mori(9), Kawanehoncho(2) \\
\hline Philippines \& Korea = 1 & & Fujikawa(7) \\
\hline Philippines \& Others $=1$ & & Kannami(8), Minamiizu(2) \\
\hline China $=1$ & Phirippines & Atami(24) \\
\hline \multicolumn{3}{|l|}{ Aichi Prefecture $=41$} \\
\hline \multirow{6}{*}{ Philippines = 31} & China & $\begin{array}{l}\text { Okazaki(213), Toyota(168), Anjo(96), Komaki(80), Kariya(77), Toyokawa(76), } \\
\text { Inuyama(48), Tokai(45), Seto(41), Iwakura(37), Konan(36), Chita(34), Heki- } \\
\text { nan(34), Toyoake(33), Obu(31), Kota(27), Gamagori(23), Higashiura(19), } \\
\text { Kira(10), Toyoyama(8) }\end{array}$ \\
\hline & China \& Korea & Shinshiro(18) \\
\hline & China \& Others & Kozakai (15), Isshiki (11), Oguchi (8) \\
\hline & Korea & Owariasahi (43), Togo (15), Hazu (9), Haruhi (9) \\
\hline & Other & Kitanagoya (39) \\
\hline & & Taketoyo (12), Otowa* (1) \\
\hline Philippines \& China $=3$ & & Nagakute (20), Jimokuji* (10), Shitara(6) \\
\hline \multirow{3}{*}{ China $=7$} & Philippines & Nisshin (24), Mihama (10) \\
\hline & Philippines \& Other & Tokoname (25), Minamichita (8), Mito* (4) \\
\hline & Other & Takahama (13) \\
\hline Korea $=1$ & Philippines & Kiyosu (23) \\
\hline \multicolumn{3}{|l|}{ Mie Prefecture $=18$} \\
\hline \multirow{2}{*}{ Philippines $=4$} & China & Tsu (92), Toin (4), Taiki (3) \\
\hline & Korea \& Other & Kihoku (4) \\
\hline Philippines \& China = 1 & & Toba (4) \\
\hline Philippines \& Others $=4$ & & Owase (4), Kumano (4), Taki (4), Meiwa (3) \\
\hline \multirow{2}{*}{ China $=3$} & Philippines & Suzuka (80), Ise (39) \\
\hline & Other & lga (21) \\
\hline China \& Others $=1$ & & Minamiise (2) \\
\hline Korea $=2$ & Philippines \& China & Inabe (14), Komono (10) \\
\hline Other $=1$ & China & Shima (18) \\
\hline Others $=2$ & & Asahi (2), Tamaki (1) \\
\hline
\end{tabular}

Data: Authors' mailed questionnaire survey.

Notes: Municipalities with "*" were merged into other municipalities after our mailed questionnaire survey.

Municipalities in RED text were designated as Underpopulated Areas.

"=Number" is the number of municipalities which are categorized as. 
tionality. Perhaps because the analysis used the total data, which failed to distinguish between husband and wife, the large number of Filipino and Chinese wives obscured the number of Brazilian and Peruvian husbands, which was low to begin with. The second reason is that Japanese-Brazilians and Japanese-Peruvians heavily engage in social interactions within their own circles and marry within them. ${ }^{17}$

\section{Geographical Background Factors of Increase in International Marriages in the Tokai Region}

\section{Analysis at prefectural level}

After Ishikawa (2007b), we again carried out correlation and regression analyses to confirm the geographical factors behind the increase in international marriages at the prefectural level in all of Japan's 47 prefectures. We used the following variable groups: 1) dependent variable: international marriage rate; 2) independent variables: male/female sex ratio of unmarried persons (age 25-39), rates of primary industry workers, secondary industry workers, manufacturing sector workers, production process workers, foreign population, and rate of increase in foreign population (Figure 2).

We obtained the following correlation coefficients between the international marriage rates and the independent variables (Table 5): sex ratio of unmarried persons, 0.674; rate of manufacturing sector workers, 0.576; rate of primary industry workers, -0.508 ; rate of secondary industry workers, 0.488 ; rate of production process workers, 0.315; foreign population rate, 0.788; and rate of increase in foreign population, -0.107 . All of these results represented strong correlation relationships, except the rate of increase in foreign population. Among the independent variables, the coefficient with the foreign population rate revealed the strongest value. These results demonstrate that not only the disparity in the sex ratio of unmarried persons but also the foreign population and the area's industrialization characteristics proved to be geographical background factors.

However, considering the scatter diagram of the rate of international marriages and the sex ratio of unmarried persons (Figure 5), when we classified the 47 prefectures into four regions (Tokai, eastern Japan, Tokyo and Osaka metropolitan regions, and western Japan), even in each regional group the sex ratio of unmarried persons had a strong positive correlation with the rate of international marriages, unlike the other independent variables. Therefore, it is reasonable to conclude that the imbalance of the sex ratio of unmarried persons was a basic background factor for international marriages. As for the area's industrialization characteristics as a geographical factor, the positively high correlation coefficients of the rates of manufacturing sector workers and production process workers with the international marriage rate might indicate that international marriages of sub-type (1b) occur in extensively industrialized prefectures.

In addition, since the disparity in the sex ratio of unmarried persons and the foreign population rate were probably correlated with the variables in other independent variable groups, especially the area's industrialization characteristics, ${ }^{18}$ we performed a multiple regression analysis using the international marriage rate as the dependent variable and the seven geographical background

Table 5. Correlation coefficients between international marriage rate and geographical background factors

\begin{tabular}{|c|c|c|c|c|}
\hline $\begin{array}{l}\text { Geographical background } \\
\text { factor group }\end{array}$ & Variables (2005) & Prefectures $(n=47)$ in Japan & $\begin{array}{c}\text { Daily-life areas }(n=40) \text { in the } \\
\text { Tokai region }\end{array}$ & $\begin{array}{c}\text { Municipalities }(n=146) \text { in the } \\
\text { Tokai region }\end{array}$ \\
\hline $\begin{array}{l}\text { Disparity in sex ratio of } \\
\text { unmarried persons }\end{array}$ & $\begin{array}{l}\text { Sex ratio of unmarried } \\
\text { persons aged } 25-39\end{array}$ & $0.674^{* * *}$ & 0.233 & 0.088 \\
\hline \multirow{4}{*}{$\begin{array}{l}\text { Area's industrialization } \\
\text { characteristics }\end{array}$} & $\begin{array}{l}\text { Rate of primary industry } \\
\text { workers }\end{array}$ & $-0.508^{* * *}$ & 0.203 & 0.099 \\
\hline & $\begin{array}{l}\text { Rate of secondary industry } \\
\text { workers }\end{array}$ & $0.488^{* *}$ & 0.275 & -0.011 \\
\hline & $\begin{array}{l}\text { Rate of manufacturing sec- } \\
\text { tor workers }\end{array}$ & $0.576^{* * *}$ & 0.286 & 0.008 \\
\hline & $\begin{array}{l}\text { Rate of production process } \\
\text { workers }\end{array}$ & $0.315^{*}$ & $0.320^{*}$ & 0.060 \\
\hline \multirow{2}{*}{ Foreign population } & $\begin{array}{l}\text { Foreign population rate } \\
\quad(2000)\end{array}$ & $0.788^{* * *}$ & 0.297 & -0.018 \\
\hline & $\begin{array}{l}\text { Increase in rate of foreign } \\
\text { population(2000-05) }\end{array}$ & -0.107 & 0.148 & $0.168^{*}$ \\
\hline
\end{tabular}

Note: ${ }^{* * *}$ : significant at $0.1 \%$ level, ${ }^{* *}$ : significant at $1 \%$ level, ${ }^{*}$ : significant at $5 \%$ level. 


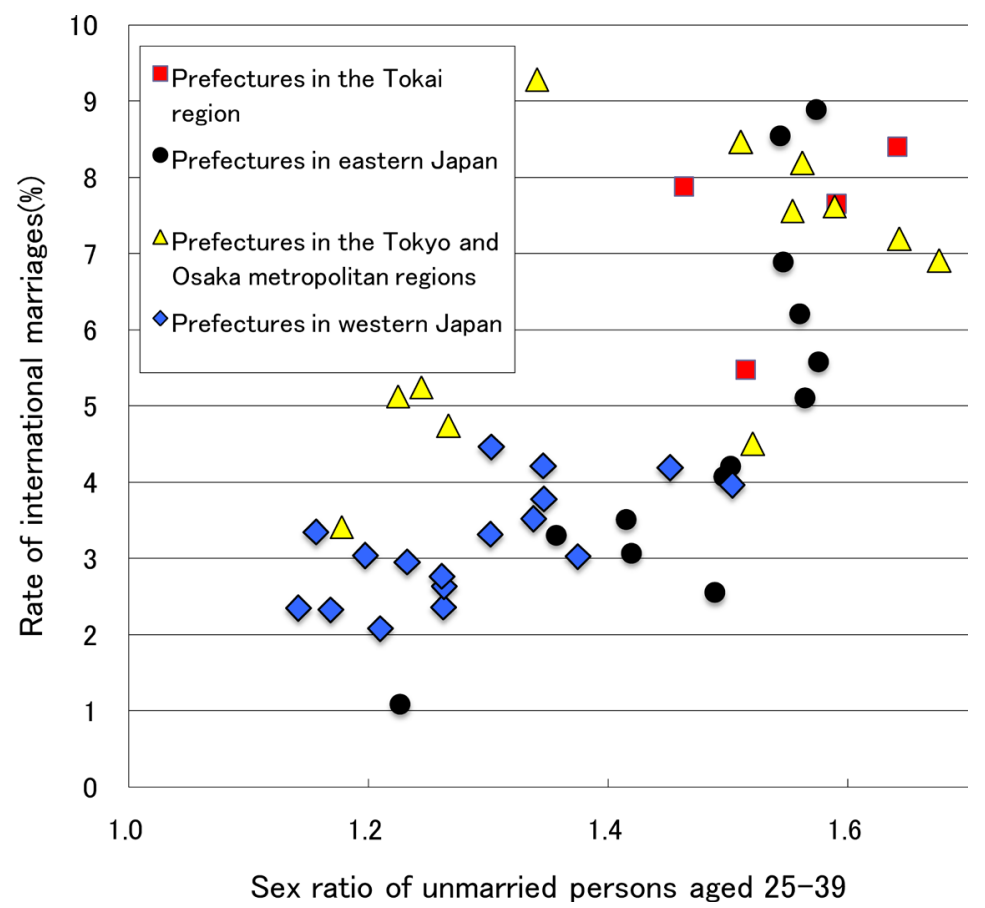

Figure 5. Scatter diagram of prefectural rate of international marriages and prefectural male/female sex ratio of unmarried persons by region.

Data: Vital Statistics of Japan in 2006 and Population Census of Japan in 2005.

indices as the independent variables as shown in Figure 2. Here, we did not use all seven independent variables at once but tried to use one, two, and three variables to find the best-fit regression equation for explaining the spatial variation of the international marriage rate. We chose one from each of the three variable groups and combined one, two, or three of the independent variables (Figure 2).

As a result, several regression analyses based on different combinations of independent variables were conducted. But of these equations, only the one with the highest explanatory power (sex ratio of unmarried persons, rate of production process workers, and foreign population rate) is shown in Table 6. This regression equation was significant at the $0.1 \%$ level, and the coefficient of determination $\left(r^{2}\right)$ was 0.836 , which was considerably higher than Ishikawa's (2007b) finding of 0.392. In other words, about $84 \%$ of the variation in the international marriage rate in the 47 prefectures can be explained by the three independent variables in this equation.

Keeping this in mind in addition to the disparity in the sex ratio of unmarried persons, we believe that the concentration of foreigners and the area's industrialization characteristics are important geographical background factors. However, the sign of the coefficient of the rate of production process workers in this equation was unexpectedly negative, which is different from the correlation coefficient with the rate of international marriages. Since the correlation coefficient between the rate of production process workers and the sex ratio of unmarried persons was 0.667 , we cannot necessarily conclude that the effect of multicolinearity between these two variables was at work. ${ }^{19}$ To carefully examine this conjecture, we conducted additional analysis of the sign of the partial regression coefficient of the rate of production process workers as well as the variables of the area's industrialization characteristics (Figure 2). When we divided the 47 prefectures into three groups in terms of the values of the sex ratio of unmarried persons to keep them nearly constant, each group had negative correlation coefficients between the rate of international marriages and the indices of the industrialization characteristics (Figure 6). In other words, the indices of the area's industrialization characteristics, especially related to the manufacturing sector, might have a slight negative effect on the development of international marriages by extracting the power of the disparity in the sex ratio of unmarried persons. This is inconsistent with our discussion that there might be many international marriages of sub-type (1b) in heavily industrialized prefectures based on our correlation analysis described above. At any rate, elucidation of this question remains a future work.

\section{Analysis on daily-life area and municipality scales}

Using exactly the same method as that applied at the prefectural level, in the Tokai region we conducted an analysis on the well-known geographical scale of daily- 
Table 6. Regression analysis of international marriage rate by geographical background factors

\begin{tabular}{|c|c|c|c|c|}
\hline Analysis level & $\begin{array}{l}\text { Dependent variable: International marriage ratio } \\
\qquad(2006)\end{array}$ & $\begin{array}{l}\text { Prefectures } \\
(n=47)\end{array}$ & Daily-life areas $(n=40)$ & Municipalities $(n=146)$ \\
\hline $\begin{array}{l}\text { Geographical background } \\
\text { factor group }\end{array}$ & Independent variables (2005) & \multicolumn{3}{|c|}{ Standardized partial coefficienet } \\
\hline $\begin{array}{l}\text { Disparity in the sex ratio of } \\
\text { unmarried persons }\end{array}$ & Sex ratio of unmarried persons aged 25-39 & $0.619 * * *$ & 0.137 & 0.151 \\
\hline \multirow{4}{*}{$\begin{array}{l}\text { Area's industrialization } \\
\text { characteristics }\end{array}$} & Rate of the primary industry workers & - & - & - \\
\hline & Rate of secondary industry workers & - & - & -0.130 \\
\hline & Rate of manufacturing sector workers & - & - & - \\
\hline & Rate of production process workers & $-0.251^{* * *}$ & - & - \\
\hline \multirow{2}{*}{ Foreign population } & Foreign population rate (2000) & $0.631^{* * *}$ & 0.244 & - \\
\hline & Increasing rate of foreign population (2000-05) & - & - & $0.216^{*}$ \\
\hline
\end{tabular}

Notes: ${ }^{* *}$ : significant at $0.1 \%$ level, ${ }^{* *}$ : significant at $1 \%$ level, ${ }^{*}$ : significant at $5 \%$ level.

"-" is not included in the regression equations with the most explanatory power.

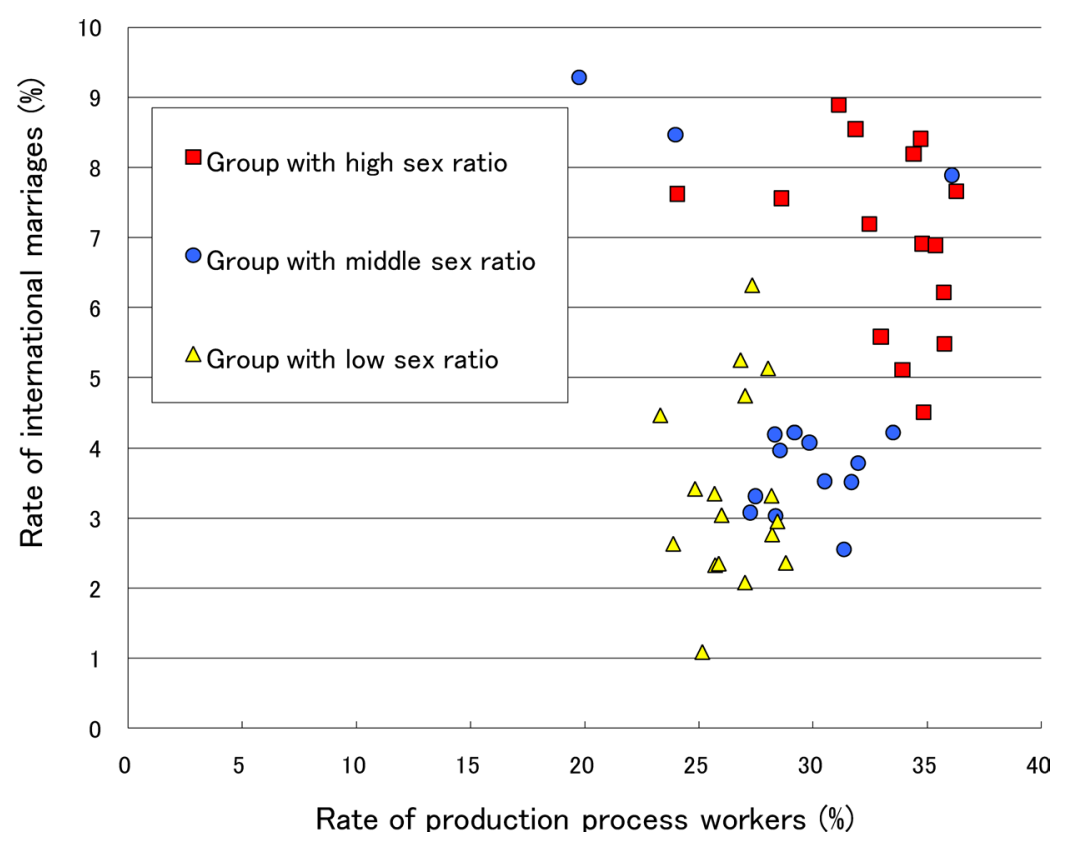

Figure 6. Scatter diagram of prefectural rates of international marriages and production process workers by group based on values of male/female sex ratio of unmarried persons.

Data: Vital Statistics of Japan in 2006 and Population Census of Japan in 2005.

life area, which is usually defined by such daily-life behavior as commuting and shopping. Since data on international marriages were not obtained from all municipalities through our mailed surveys, we took into account the existence of non-responding municipalities when conducting the analysis at the daily-life area level. In this context, it is important to note that the Japanese national government introduced a policy of municipal mergers throughout Japan from 1999 to 2010 (also see note 10). In this pro-merger policy, the targeted size of the newly merged municipalities is likely to nearly equal the dailylife areas. As a result of this consolidation policy, many newly enlarged municipalities appeared in the Tokai region. Considering this background, we selected, as the target of our analysis, daily-life areas from which we got responses from two or more of their municipalities or, in the case where the daily-life area was composed of only two municipalities, from one municipality. Using this procedure, we obtained the international marriage rates of 40 among all 42 daily-life areas. 
The correlation coefficients obtained from the analysis on the scale of daily-life area are shown in Table 5. The following are the correlation coefficients with values over 0.2 : sex ratio of unmarried persons: 0.233 , rate of production process workers: 0.320 , rate of manufacturing sector workers: 0.286 , and foreign population rate: 0297 . Overall, we only obtained low correlation coefficients. Of these variables, the correlation coefficient of the production process worker rate $(0.320)$ was statistically significant at the $5 \%$ level in the Tokai region, which was particularly low compared to the coefficients obtained at the prefectural level. In other words, on the daily-life area scale, we found almost no relationship between international marriage rate and the disparity in the sex ratio of unmarried persons or the foreign population rate.

Following the above correlation analysis, we next carried out a regression analysis using the same method as for the prefectural level. Even in Table 6, showing the best regression equation, there was no statistical significance even at the $5 \%$ level, and the coefficient of determination (0.105) had almost no explanatory power. There were also no independent variables at the $5 \%$ level. Hence, we have to conclude that the results of the correlation and regression analyses indicate that daily-life areas were not meaningful as a geographical scale to explain the increase in international marriages.

We obtained the international marriage rates of 146 municipalities in the Tokai region and analyzed them employing the same methods mentioned above (Tables 5 and 6). The results reveal that all of the correlation coefficients were near zero, indicating no correlation between the international marriage rate and the indices used as independent variables. As for the results of the regression analysis, coefficient of determination for the highest explanatory power for the best regression equation was merely 0.051 , implying there was no substantially meaningful regression equation.

These results suggest that important geographical boundaries for the increase in international marriages transcend the boundaries of the daily-life areas and the municipalities and that, perhaps, they are most meaningful on the prefectural scale. This is partly consistent with Suzuki's (1990) observation in which he pointed out that, based on a 1987 nation-wide survey ${ }^{20}$ on marriages conducted by the Institute of Population Problems, Ministry of Health and Welfare, both the brides and the grooms in $80 \%$ of newly married couples in Japan had lived in the same prefecture.

\section{Conclusions}

The purpose of this article was to examine the salient features of international marriages both at the prefectural and municipal levels in the four prefectures of the Tokai region (Gifu, Shizuoka, Aichi, and Mie) and to identify the important geographical background factors affecting them. Here, we summarize our findings.

The international marriage rates in Gifu, Shizuoka, and Aichi Prefectures exceeded Japan's overall rate. Of these marriages, the Japanese husband and foreign wife type comprised more than $80 \%$. More than $80 \%$ of the foreign wives' nationalities include Asian countries, particularly the Philippines. This was different from the national trend where Chinese nationality was the most frequent. As for the nationality of foreign husbands, Brazilians have been the most frequent in Gifu and Shizuoka in recent years, and even in Mie the Brazilian nationality rate has been growing. Many important industrial areas in Japan are located in the Tokai region, where large numbers of Japanese-Brazilians have also settled as workers.

Although the Tokai region is only a small part of Japan, our study was the first to obtain data concerning the increase in international marriages and the nationality of foreign spouses at the municipal level. As a result, we found that municipalities with a high international marriage rate included underpopulated areas in mountainous and peninsular regions as well as industrial areas, especially large cities where the manufacturing sector was very influential. In the municipal groups described above, the most typical international marriages involve couples of male successors to farming households and Asian females or blue-collar male workers and Asian females.

Next, we found that in the municipalities of the three Tokai prefectures with many international marriages (i.e., excluding Mie Prefecture), the most common ranking of foreign spouses' nationalities was Filipino first followed by Chinese. The fact that Filipinos occupied the first rank of foreign spouse nationalities both at prefectural and municipal levels in these three prefectures might be traced back to the late 1980s to mid-2000s, when a substantial female Filipino population came to the Tokai region as "entertainers."

To identify the geographical factors affecting the increase in international marriages, we performed statistical analyses at the prefectural level (47 prefectures) throughout Japan, at the daily-life area level (40 daily-life areas), and at the municipal level (146 municipalities) in this region. We used the international marriage rate as a dependent variable, and the three geographical background 
groups of the disparity in the sex ratio of unmarried persons, the area's industrialization characteristics, and the foreign population as independent variables. The results of regression analyses for the 47 prefectures reveal that the disparity in the sex ratio of unmarried persons, the area's industrialization characteristics, and the foreign population are important geographical background factors affecting international marriage. Another interesting finding of this paper is that as the spatial scale for analysis became lower, almost no convincing geographical background factors could be found, at either the daily-life area or the municipality level. Based on our statistical analysis of geographical background factors, we can conclude that explanations only at the prefectural level as a geographical unit were highly meaningful. This is partly because at least one third of all international marriages in Japan are assumed to occur through matchmaking agencies that use web sites for their business advertisements, and these tend to attract male applicants as their customers mainly within a particular prefecture (Ishikawa 2010).

Moreover, based on our interviews with international matchmaking agencies in the Tokai region, the Japanese men seeking international marriages are not limited to male successors of farming households or blue-collar workers but also include middle-aged men, divorced men, and white-collar workers who lack opportunities to get acquainted with potential spouses. Such trends are basically consistent with the findings obtained by this paper's investigations using regression analysis. Considering that one third of all international marriages involve matchmaking agencies that employ web sites and gather applicants mainly from the prefectures in which they are based, and that even white-collar workers select international marriages to overcome their difficulties in getting married, international marriages have come to represent a new style of marriage formed in the information society of a globalized era.

\section{Acknowledgements}

We thank the municipal governments that provided international marriage data and the officials of support organizations for foreigners and international marriages who gave us interviews. We are deeply indebted to Professor Takashi Abe (Nihon Women's College), Professor Sachi Takahata (University of Shizuoka), Professor Mordecai G. Sheftall (Shizuoka University), and Lecturer Max Praver (Shizuoka University). We also thank anonymous referees for helpful suggestions. However, the authors assume responsibility for any errors in this paper. We re- ceived financial aid from the Japan Society for the Promotion of Science through grants-in-aid (no. 18320134 and 21242032).

\section{Notes}

1. Data source is Population Census of Japan.

2. According to School Basic Survey by the Ministry of Education, Culture, Sports, Science and Technology.

3. Based on Population Census of Japan.

4. The following are the reasons given by women from 25-34 for remaining single, in descending order: "difficult to meet a suitable man," "don't want to sacrifice my freedom," "no interest in marriage," "prefer hobbies," and "prefer concentrating on my career."

5. This phrase has appeared in magazines and books since 2006. Recently in Japan, some men seem less interested in dating or having girlfriends, but they are enthusiastic about their hobbies. Since they don't seem interested in relationships with women, they are called "herbivorous men."

6. Under the second demographic transition, many industrialized countries in East Asia have higher rates of international marriage than Japan. For example, according to Ochiai et al. (2007), the international marriage rate was $13.6 \%$ (2005) in Korea.

7. The Vital Statistics of Japan defines an international marriage as one in which the husband or the wife has foreign nationality and the other spouse has Japanese nationality. After 1947, the descendants of the Korean and Taiwanese "old comers" from former Japanese colonies didn't have Japanese nationality but instead were granted a legal status called "special permanent resident" by the Japanese government. Since then, about 500,000 people have lived as foreigners under this status. The marriages between them and Japanese are thus classified as international. Until 1985, the share of such international marriage couples was estimated to be more than $50 \%$ of all international marriages almost every year, owing to the large population of the old comers' descendants.

8. After 2006, the number and rate of international marriages in Japan rapidly decreased, possibly owing to Japan's economic recession, especially following the Lehman Brothers Crisis in 2008.

9. In Japan, a marriage registration can be submitted by a married couple to the municipal government where a husband/wife currently resides (gen-jusho) or where his/her family is officially registered (honseki-chi). However, in most cases, it is submitted to the municipality in which he/she (or both) resides. Therefore, we categorized the number of marriage registrations received by each municipality as the number of marriages by municipality. Note that the number of marriages by prefecture in Vital Statistics of Japan is based on the residential address (gen-jusho) of the husband when the marriage registration was submitted.

10. The national government introduced a policy that merged municipalities from 1999 to 2010 throughout Japan. Some were merged into new, enlarged municipalities after our questionnaire survey was finished.

11. Based on Ishikawa (2007b), we adopted the 25-39 age range as the marriageable age.

12. According to Ochiai et al. (2007), based on the micro-data sample of the Population Census in 2000, new foreign brides in Miyagi, Yamagata, and Fukushima Prefectures accounted for about 50\% of the new arrivals of foreign females.

13. The Ministry of Justice adopted strict immigration policies for the residence status of "entertainers" in 2005. As a result, the number of newly entering Filipino nationals possessing the residence status of "entertainer" drastically decreased from 82,741 in 2004 to 47,765 in 2005 and 8,604 in 2006 . The year of 2005 was a pivotal year in which the number of such new arrivals as entertain- 
ers decreased while the number of Filipino arrivals as spouses of Japanese nationals increased from 8,517 in 2004 to 12,150 in 2006 (Takahata 2011).

14. We obtained the data of international marriage rates of Nagoya and Shizuoka Cities as Ordinance-designated Cities through Vital Statistics of Japan 2006 and those of 146 municipalities through our questionnaires.

15. Traditionally in Japan, new brides in rural areas are likely to get married to grooms in urban areas as a kind of hypergamy. A large part of the movement of brides has been in the downstream direction of river drainage areas. In other words, grooms in the urban areas of downriver regions get brides from upriver regions. Consequently, grooms in the mountainous areas in the most upriver regions, who can't seek brides for themselves, must rely on foreign countries (Kojima 1989).

16. It seems curious, but some highly industrialized or large cities, such as Toyota, Hamamatsu, and Tsu, are classified as Underpopulated Areas in Tables 3 and 4 because they have subsumed the Underpopulated Areas in their vicinities, in accordance with the national pro-merger policy of municipalities from April 1999.

17. This is based on our interview survey with officials from support organizations for foreigners in Hamamatsu City.

18. For the foreign population rate, the variables with correlation coefficients higher than 0.5 were the rates of primary industry workers $(-0.705)$ and manufacturing sector workers $(0.573)$. For the sex ratio of unmarried persons, the variables with higher correlation coefficients than 0.5 were the rates of secondary industry workers (0.697), manufacturing sector workers (0.668), and production process workers $(0.666)$. The correlation coefficient between the sex ratio of unmarried persons and the foreign population rate was only 0.353 .

19. We did not significantly doubt the influence of multicollinearity among the independent variables for the following reasons: 1) the correlation coefficient of the sex ratio of unmarried persons and the rate of production process workers was below $0.7 ; 2$ ) the Variance Inflation Factors (VIFs) of the three independent variables were under 2.0. However, an examination of multicollinearity by tests using measures of the eigenvalue and the condition number on each independent variable suggests a slight doubt of this influence.

20. Based on the 9th National Fertility Survey, conducted by the Institute of Population Problems, the Ministry of Health and Welfare.

\section{References}

Abe, R. 2003. The formation of space of Philippine Pubs and the social construction of representations of ethnicity: A case study of Sakae Walk Street in Nagoya City. Japanese Journal of Human Geography 55(4): 1-23. (JE)

Chiba, T. 2012. Residential distribution of foreign people in Japan. Tokei (Statistics) 63(4): 16-22. (J)

Ishikawa, Y. ed. 2007a. Jinko gensho to chiiki: Chirigaku-teki apurochi (Population decline and regional imbalance: Geographical perspectives). Kyoto: Kyoto University Press. (J)
Ishikawa, Y. 2007b. Imbalanced sex ratio and international marriage in contemporary Japan. In Gurobaru-jidai no jinbungaku: Taiwa to kan'yo no chi wo motomete, Ge: Kyousei heno toi (The humanities in the age of globalization: In search of intellectual frameworks of dialogue and tolerance, II: Questions for coexistence), ed. E. Kihira, 127-145. Kyoto: Kyoto University Press. (J)

Ishikawa, Y. 2010. Role of matchmaking agencies for international marriage in contemporary Japan. Geographical Review of Japan Series B 83: 1-14.

Kojima, H. 1989. International marriages. Tokei (Statistics) 40(2): 18-25. (J)

Mitsuoka, K. 1989. Nosonkazoku no kekkon-nan to koreisha mondai (Marriage squeeze of rural village families and problem of the elderly). Kyoto: Mineruva-shobou. (J)

Mlädek, J. and Malenchowa, J. 2008. Recent population changes in Slovakia: From the viewpoint of the second demographic transition. In Comparative study of family, lifestyle and population: Slovakia and Japan, ed. K. Kobayashi, T. Kobayashi and Y. Ozeki, 7-27. Tokyo: Ninomiya-shoten. (J)

Nakazawa, S. 1996. Lives and consciousness of foreign wives from Asia in Japanese rural villages: Chinese/Taiwanese, Korean and Filipina brides in Mogami District, Yamagata Prefecture. Japanese Journal of Family Sociology 8: 81-96. (JE)

National Institute of Population and Social Security Research 2007. Report on the thirteenth Japanese national fertility survey in 2005, volume II: Attitudes toward marriage and family among Japanese singles. Tokyo: National Institute of Population and Social Security Research. (J)

Ochiai, E., Liaw, K. and Ishikawa, Y. 2007. Feminization of immigration to Japan: Mainly focused on international marriage. In Jinko gensho to chiiki: Chirigaku-teki apurochi (Population decline and regional imbalance: Geographical perspectives), ed. Y. Ishikawa, 291-319. Kyoto: Kyoto University Press. (J)

Sugai, K. 2006. Jichitai ga sendoshita Showa no kokusaikekkon: Yamagata Ken Asahi Machi (International marriages led by a municipal government in the Showa Era: The case of Asahi Town, Yamagata Prefecture). Gekkan Jichiken (Monthly Report on Municipal Governments) 48(10): 61-69.(J)

Suzuki, T. 1990. Interregional marriage in Japan(1). Jinko Mondai Kenkyu (Journal of Population Problems) 46(2): 17-32. (JE)

Takahata, S. 2011. The Filipino migrants in Japan as of 2010: The aging of the first generation and the "repatriation" of acknowledged Japanese-Filipinos. Buraku Kaiho Kenkyu (Research on Buraku Liberation) 17: 67-83.(J)

Takeshita, S. 2004. Kokusai kekkon no shoso (Various aspects of international marriage). Tokyo: Gakubun-sha. (J)

(J) written in Japanese

(JE) written in Japanese with English abstract 